\title{
PENGARUH PEMANFAATAN SOSIAL MEDIA, MOTIVASI DAN \\ PENGETAHUAN TERHADAP MINAT BERWIRAUSAHA \\ PADA MAHASISWA EKONOMI DI UNIVERSITAS MUHAMMADIYAH SIDOARJO
}

\author{
Muhammad Hasym Alfaruk, Pascasarjana Unesa \\ Alfarukpascaunesa1@gmail.com
}

\begin{abstract}
ABSTRAK
Penelitian ini bertujuan untuk menganalisis pengaruh pemanfaan sosial media, motivasi dan pengetahuan terhadap minat berwirausaha pada mahasiswa Ekonomi Universitas Muhammadiyah Sidoarjo baik secara parsial maupun simultan. Penelitian yang dilakukan merupakan penelitian kuantitatif. Populasi dalam penelitian ini mahasiswa Ekonomi angkatan tahun 2009-2010 sampai sebanyak 650 dengan jumlah sampel sebanyak 247 mahasiswa. Metode analisis data menggunakan teknik analisis regresi linier berganda. Hasil penelitian menunjukkan bahwa secara parsial pemanfaatan sosial media dan motivasi berpengaruh signifikan terhadap minat berwirausaha pada mahasiswa Ekonomi Universitas Muhammadiyah Sidoarjo, sedangkan Pengetahuan tidak memiliki pengaruh terhadap minat berwirausaha pada mahasiswa Ekonomi Universitas Muhammadiyah Sidoarjo. Secara simultan pemanfaatan sosial media, motivasi dan pengetahuan berpengaruh signifikan terhadap minat berwirausaha pada mahasiswa Ekonomi Universitas Muhammadiyah Sidoarjo.
\end{abstract}

Kata Kunci: pemanfaatan sosial media, motivasi, pengetahuan, minat berwirausaha

\begin{abstract}
This study aimed to analyze the influence of social media utilization, motivation and knowledge of student interest in entrepreneurship at the Economic University of Muhammadiyah Sidoarjo either partially or simultaneously. Research conducted a quantitative study. The population in this study Economy class students in 2009-2010 to 650 with a total sample of 247 students. Methods of data analysis using multiple linear regression analysis technique. The results showed that the partial use of social media and motivation significant effect on student interest in entrepreneurship at the Economic University of Muhammadiyah Sidoarjo, while knowledge has no influence on the interest in entrepreneurship in students of Economics, University of Muhammadiyah Sidoarjo. Simultaneous use of social media, motivation and knowledge significantly influence student interest in entrepreneurship at the Economic University of Muhammadiyah Sidoarjo.
\end{abstract}

Keywords: the use of social media, motivation, knowledge, interest in entrepreneurship 


\section{PENDAHULUAN}

Tantangan untuk mencari kerja di kalangan lulusan perguruan tinggi semakin ketat dan jumlah peluang penawaran kesempatan kerja tidak sebanding dengan jumlah lulusan atau penawaran tenaga kerja baru disegala level Pendidikan (Saiman, 2009). Memiliki pekerjaan yang mapan merupakan idaman setiap orang khusunya bagi mahasiswa yang baru selesai menyelesaikan studi di perguruan tinggi, apalagi kalau pekerjaan yang diperoleh sesuai dengan kompetensi yang dikuasai. Kompetensi yang telah ditekuni selama menempuh kuliah di perguruan tinggi akan lebih bermanfaat apabila diterapkan dalam dunia kerja. Kewirausahaan termasuk kompetensi yang diajarkan oleh perguruan tinggi terbukti ada mata kuliah Kewirausahaan yang berjumlah 2 Sks setiap fakultas ekonomi. Mahasiswa diajari memahami teori tentang kewirausahaan, kemudian diterapkan dalam suatu bentuk praktek usaha sendiri yang difasilitasi juga oleh perguruan tinggi.

Berdasarkan kondisi tersebut Maka Universitas Muhammadiyah Sidoarjo khususnya Fakultas Ekonomi yang turut berkotmitmen mencetak mahasiswanya agar menjadi generasi yang mandiri dan kreatif. Hal tersebut terdapat dalam Slogan Fakultas Ekonomi "Live Entrepreneur". Untuk mengembangkan Kewirausahaan di kalangan mahasiswa Universitas Muhammadiyah Sidoarjo perlu dilakukan berbagai upaya untuk menumbuhkan minat mereka berwirausaha . Dalam hal ini Universitas Muhammadiyah Sidoarjo berperan besar dan strtaegis dalam mengubah, Sikap Mahasiswa dari mencari kerja menjadi pencipta lapangan kerja (Wirausaha). Terbukti dengan mahasiswa yang sudah dikenalkan dengan dunia usaha sejak awal masuk kuliah. Pada saat orientasi mahasiswa (Ospek) di fakultas Ekonomi mahasiswa dibekali dengan mentoring kewirausahaan dan diberi kesempatan untuk membuat bisnis. Dalam mengembangkan dan menumbuhkan semangat berwirausaha bagi mahasiswa, di falkultas Ekonomi Universitas Muhammadiyah mempunyai berbagai macam kegiatan kewirausahaan . Diantaranya terdapat Economic Entrepreneur Building community (EEBC), PMW (Program Mahasiswa Wirausaha) PKM-K (Program Kreativitas Mahasiswa - Kewirausahaan) Bussines Plan Competition, terdapat juga kegiatan Bazar rutin diselenggarahkan setiap tahunnya.

Sosial media memberikan terobosan untuk merubah pola pikir dilingkungan mahasiswa fakultas ekonomi universitas muhammadiyah sidoarjo untuk berwirausaha bisa memperkecil resiko untuk gagal dan mempermudah untuk memasarkan produk lebih luas tanpa biaya yang sangat tinggi. Untuk menjadi wirausaha yang sukses mahasiswa harus bisa memperluas jaringan yang luas untuk lebih berkomunikasi dengan yang lain (Herwaman Kartajaya, 2008) dengan cara menggunakan internet. Dikarenakan peran sosial media semakin diakui dalam mendongkrak kinerja dalam dunia bisnis. Efektivitas pemanfaatan tergantung pada bagaimana pemilik merek menggunakannya seperti Samsung, Blackberry bahkan Apple adalah merek yang global dan sukses didorong oleh dahsyatnya media sosial.

Ditengah maraknya pengguna Sosial media dari tahun ke tahun, semakin banyak pula bisnis yang telah dirilis melalui media sosial. Entah itu melalui Blog, twitter, Instagram, Kaskus, Facebook bahak Whatshaap ataupun fitur-fitur 
Smartphone seperti Blackberry Messegger (BBM) hal ini tertentu memberikan kesempatan bagi pemasaran elektronik (Sebagai fenomena di dunia pemasaran) untuk bertumbuh secara dinamis. Hal ini bisa dijadikan sebagai peluang yang bagus bagi wirausaha kedepanya guna menggali potensi berwirausaha melalui media sosial. Apalagi sekarang sudah ada sosial media yang menfasilitasi setiap orang untuk terhubung satu sama lain. Menjual maupun mempromosikan barangbarang pun dapat memangkas biaya yang tidak terlalu besar. Anda tidak perluh menyewa tempat, membuat barner ataupun memasang iklan dikoran dengan biaya mahal

Faktor lain yang berpengaruh terhadap minat mahasiswa dalam berwirausaha adalah Motivasi. Motivasi sebagai salah satu faktor pendukung penting yang dapat mendorong keberanian seseorang untuk memutuskan berwirausaha.sangat perluh dibutuhkan dalam diri seorang mahasiswa yang khusunya pada mahasiswa Fakultas Ekonomi di Universitas Muhammadiyah Sidaorjo.Motivasi yang dimaksudkan disini adalah motivasi interistik mahasiswa yaitu motivasi yang timbul dalam diri individu mahasiswa itu sendiri. Mengingat motivasi ekstristik yaitu motivasi yang timbul sebagai akibat pengaruh dari luar yaitu dalam hal ini Universitas maupun Lingkungan yang telah mencoba memberikan pengetahuan tentang berwirausaha pada Mahasiswa.

Meskipun motivasi telah diberikan namun pada kenyataanya kurang bisa memberikan dorongan pada siswa untuk berminat dalam berwirausaha disebabkan masih sangat rendahnya motivasi dalam diri mahasiswa Fakultas Ekonomi Universitas Muhammadiyah untuk berwirausaha. Rendahnya motivasi siswa dilihat dari (1) ketidak mandirian mahasiswa dalam penyelesaian tugas yang diberikan dosen, mahasiswa masih cenderung mengharapkan batuan temanya untuk menyelesaikan tugas mereka daripda berusaha sendiri (2) tidak memiliki motif berprestasi tinggi, hal ini dapat terlihat dari sikap mahasiswa yang suka alasan - alasan jika diberiakn tugas dan seirng mengerjakan pekerjaan rumah di kampus. Padahal untuk menjadi wirausaha dibutuhkan antara lain sikap kemandirian, dan keinginan untuk selalu menghasilkan suatu yang terbaik (Keinginan berprestasi).

Selain motivasi, pengetahuan, minat seorang dalam berwirausaha juga dipengaruhi oleh pengetahuan tentang kewirausahaan itu sendiri. Seorang wirausahawan tidak akan berhasil apabila tidak memiliki pengetahuan, kemampuan dan kemauan. Ada kemauan tapi tanpa kemampuan dan pengetahuan tidak akan membuat wirausahawan itu menjadi sukses, sebaliknya memiliki pengetahuan dan kemampuan tanpa didasari oleh kemauan yang kuat tidak akan mengantarkan wirausaha itu juga pada kesuksesan.

Ditambah oleh Alma (2013) bahwa "bakat seseorang wirausaha akan bertambah dan berkembang berkat pengetahuan" Dari uraian tersebut diatas dapat dilihat bahwa untuk menumbuhkan minat berwirausaha juga memerluhkan pengetahuan kewirausahaan, sebab dengan bekal pengetahuan yang cukup mereka akan bisa menjalankan usahanya dengan baik. Upaya yang sama coba dilakukan oleh Universitas Muhammadiyah Sidoarjo untuk meningkatkan penguasaan pengetahuan bagi mahasiswa Ekonomi Universitas Muhammadiyah Sidoarjo sendiri. Mengingat penguasaan pengetahuan kewirausahaan mahasiswa Ekonomi Universitas Muhammadiyah Sidoarjo dirasakan masih sangat kurang, hal ini dilihat dari tidak ada perubahan pola pikir mahasiswa tentang kewirausahaan 
setelah mendapatkan mata kuliah Kewirausahaan di Universitas Muhammadiyah Sidoarjo.

Dengan demikian, tujuan dalam penelitian ini antara: (a) Menganalisis pengaruh pemanfaatan sosial media, motivasi dan pengetahuan terhadap minat berwirausaha mahasiswa Fakultas Ekonomi Universitas Muhammadiyah Sidoarjo secara parsial: (b) Menganalisis pengaruh pemanfaatan sosial media, motivasi dan pengetahuan terhadap minat berwirausaha mahasiswa Fakultas Ekonomi Universitas Muhammadiyah Sidoarjo secara simultan.

\section{METODE PENELITIAN}

Pendekatan penelitian ini adalah pendekatan kuantitatif dengan menggambarkan regresi linier berganda, jadi ada variabel bebas dan variabel terikat. Variabel bebas dalam penelitian ini adalah sosial media, motivasi dan pengetahuan sedangkan variabel terikat minat berwirausaha $(\mathrm{Y})$ ketiga variabel $\mathrm{X}_{1}, \mathrm{X}_{2}$ dan $\mathrm{X}_{3}$ akan dianalisis pengaruh masing - masing variabel bebas tersebut pada variabel terikat (Y). Analisis tersebut kemudian menganalisis kedua variabel bebas tersebut kemudian dilanjutkan dengan menganalisis kedua variabel bebas tersebut secara bersama - sama. Penelitian ini melihat pengaruh antar variabel bebas dan terikat sehingga dalam penelitian ini dirancang sebagaimana yang ditunjukan dibawah ini :

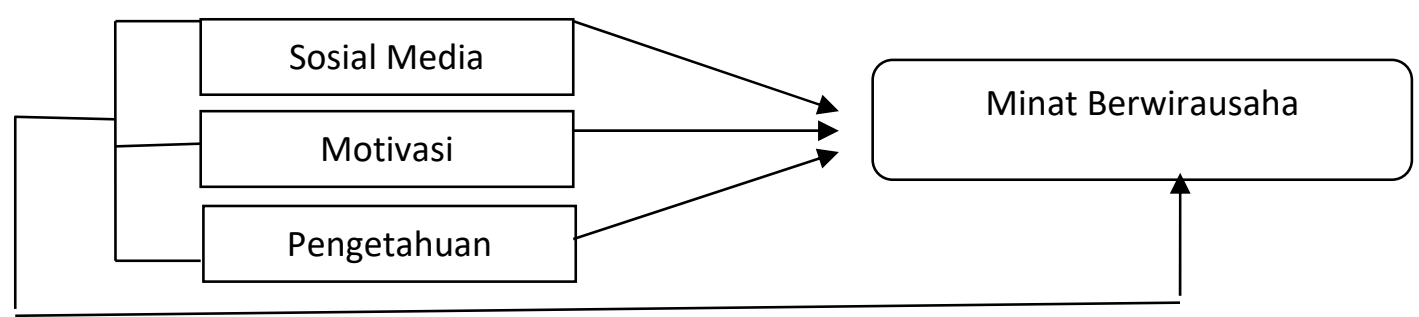

Gambar 1. Paradigma Penelitian

Populasi pada penelitian ini adalah semua mahasiswa fakultas ekonomi di Universitas Muhammadiyah Sidoarjo adalah 650 mahasiswa yaitu mahasiswa yang pernah mendapatkan mata kuliah kewirausahaan yang sebagai subjek penelitian dengan pertimbangan bahwa mahasiswa yang setelah mendapatkan mata kuliah kewirausahaan dan praktek kewirasuahaan dilapangan. Metode penelitian sampel yang digunakan adalah probability sampling. Alasan digunakan teknik ini karena banyaknya sampel yang akan dipilih, sesuai dengan populasi yang terindentifikasi sedangkan jenis metode normal probability random sampling yang digunakan adalah normal probability random sampling yaitu cara pengambilan dari sampel anggota populasi dengan menggunakan penentuan sampel dengan pertimbangan tertentu dan dilakukan pengambilan secara acak. Hal ini dilakukan apabila populasi dianggap sejenis (homogen). Sehingga sampel yang diperoleh adalah 247 mahasiswa.

Metode pengumpulan data yang digunakan dalam penelitian ini adalah observasi, dokumentasi dan angket. Dokumentasi yang digunakan untuk 
memperoleh data sekunder yang berupa data atau benda-benda tertulis seperti buku-buku, dokumen, atau catatan-catatan dari fakultas atau jurusan yang berisikan jumlah mahasiswa semester 2011-2013, atau jumlah mahasiswa yang telah menempuh mata kuliah kewirausahaan, dan sebagainya. Angket atau kuesioner digunakan untuk mengumpulkan data primer atas variabel sosial media, motivasi, pengetahuan dan minat berwirausaha mahasiswa. Sedangkan metode observasi dilakukan untuk memperoleh data dan informasi tersebut berupa fenomena, sifat dan jumlah populasi dan kurikulum yang digunakan sekolah.

Analisis regresi linier berganda ini menggunakan uji asumsi klasik (Ghozali,2005) diantaranya yang digunakan dalam penelitian ini adalah uji normalitas, uji multikolinier, uji heteroskedastisitas, uji linieritas. Terdapat dua uji statistik yang digunakan dalam penelitian ini yaitu uji $t$ dan uji $F$. Uji $t$ digunakan untuk mengetahui ada atau tidaknya pengaruh sosial media $\left(\mathrm{X}_{1}\right)$, motivasi $\left(\mathrm{X}_{2}\right)$, pengetahuan $\left(\mathrm{X}_{3}\right)$ secara parsial terhadap minat berwirausaha (Y). Uji $\mathrm{F}$ digunakan untuk mengetahui ada atau tidaknya pengaruh sosial media $\left(\mathrm{X}_{1}\right)$ motivasi $\left(\mathrm{X}_{2}\right)$, pengetahuan $\left(\mathrm{X}_{3}\right)$ secara simultan terhadap minat berwirausaha $(\mathrm{Y})$.

\section{HASIL PENELITIAN DAN PEMBAHASAN}

Berdasarkan hasil uji normalitas dengan menggunakan grafik histogram diketahui bahwa grafik histogram arah garis yang sesuai antara kiri dan kanannya. Sedangkan dapat juga dilihat melalui p-plot yang diketahui bahwa data yang berupa titik - titik pada grafik P - Plot menyebar disekitar garis diagonal dan mengikuti arah garis diagonal, sehingga distribusi residualnya memenuhi asumsi normalitas. dikethaui bahwa nilai torelance dan VIF yang dihasilkan oleh variabel pemanfaatan sosial media $\left(\mathrm{X}_{1}\right)$ adalah 0,966 untuk nilai torelace (Kurang dari 1) dan nilai $\mathrm{F}$ adalah 1,035 (kurang dari angka 10) sedangkan variabel motivasi $\left(\mathrm{X}_{2}\right)$ adalah 0,960 untuk nilai tolerance (Kurang dari angka 1) dalam nilai VIF adalah 1,042 (Kurang dari angka 10) dan untuk variabel Pengetahuan kewirausahaan $\left(\mathrm{X}_{3}\right)$ adalah 0,987 untuk nilai tolerance (Kurang dari angka 1) dalam VIF adalah 1,013 (Kurang dari angka 10) sehingga variabel dari ketiga bebas tidak terjadi Multikolinieritas.Sedangkan untuk uji Heterokedastistas menunjukan titik - titik menyebar secara acak serta tersebar dengan baik diatas maupun dibawah angka 0 pada sumbu Y seperti pada Grafik Berikut :.

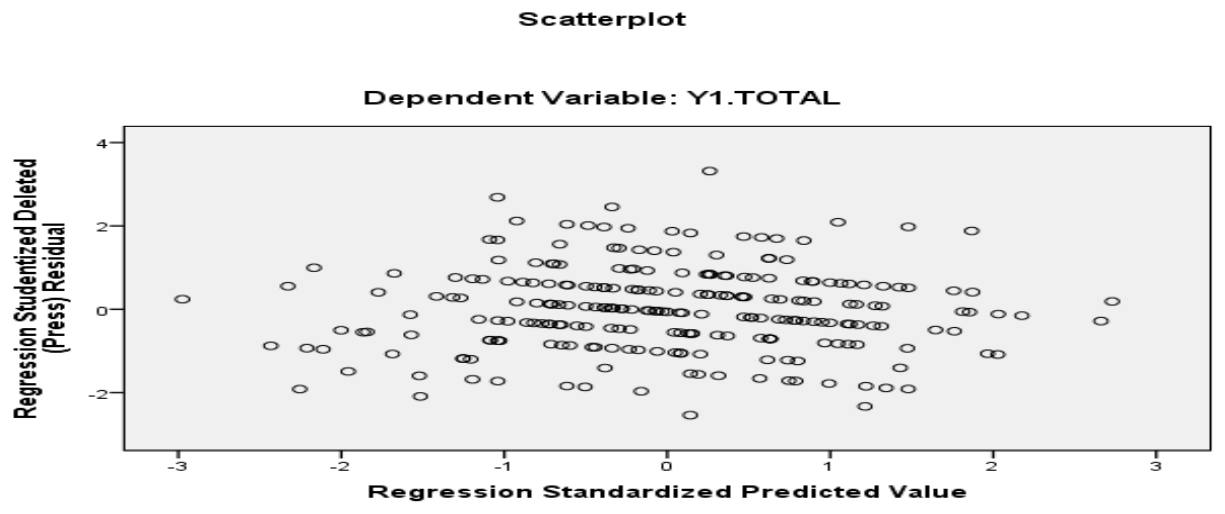


Hal ini dapat disimpulkan bahwa tidak terjadi heteroskedastisitas pada model regresi sehingga model regresi layak dipakai untuk memprediksi variabel pemanfaatan sosial media, motivasi dan pengetahuan terhadap minat berwirausaha. bahwa nilai signifikan variabel pemanfaatan sosial media yaitu 0,522 yang menandakan bahwa nilai tersebut lebih besar dari 0,05 . artinya terdapat hubungan linier secara signifikan antara variabel pemanfaatan sosial media $\left(\mathrm{X}_{1}\right)$ dengan minat berwirausaha $(\mathrm{Y})$. sedangkan nilai signifikan variabel motivasi $\left(\mathrm{X}_{2}\right)$ yaitu 0,423 yang menandahkan bahwa nilai tersebut lebih besar dari 0,05 yang artinya terdapat hubungan linier secara signifikan antara variabel minat berwirasuaha (Y). sedangkan yang terakhir nilai signifikan variabel pengetahuan kewirausahaan $\left(\mathrm{X}_{3}\right)$ yaitu sebesar 0,900 yang menandakan bahwa nilai tersebut lebih besar dari 0,05 yang artinya terdapat hubungan linier secara signifikan antara variabel minat berwirausaha.

Berdasarkan uji signifikansi yang telah dilakukan maka model persamaan regresi dapat ditulis dalam bentuk persamaan regresi linier berganda sebagai berikut

\begin{tabular}{|c|c|c|c|c|c|}
\hline \multirow[b]{3}{*}{ Model } & \multicolumn{3}{|c|}{ Coefficients $^{\mathrm{a}}$} & \multirow[b]{3}{*}{$t$} & \multirow[b]{3}{*}{ Sig. } \\
\hline & \multicolumn{2}{|c|}{$\begin{array}{l}\text { Unstandardized } \\
\text { Coefficients }\end{array}$} & \multirow{2}{*}{$\begin{array}{c}\begin{array}{c}\text { Standardize } \\
\text { d }\end{array} \\
\text { Coefficients } \\
\text { Beta }\end{array}$} & & \\
\hline & B & $\begin{array}{l}\text { Std. } \\
\text { Error }\end{array}$ & & & \\
\hline 1 (Constant) & 18,111 & 1,825 & & 9.922 & .000 \\
\hline Sosial media & $.0,87$ & .042 & .131 & 2.073 & .039 \\
\hline Motivasi & .118 & .039 & .193 & 3.045 & .042 \\
\hline $\begin{array}{l}\text { Pengetahuan } \\
\text { Kwu }\end{array}$ & -.057 & .048 & -.074 & -1.189 & -.152 \\
\hline
\end{tabular}

a. Dependent Variable: Minat Berwirausaha

$$
\left.: \mathbf{Y}=18,111+0,087 \mathbf{X}_{1}+0,118 \mathbf{X}_{2}+(-0,057) \mathbf{X}_{\mathbf{3}}+\mathbf{e i}\right)
$$

Berdasarkan uji hipotesis pertama, nilai t-hitung pada variabel pemanfaatan sosial media $\left(\mathrm{X}_{1}\right)$ sebesar 2.073 lebih besar dari $\mathrm{t}$ - tabel 1,66 dan nilai signifikan 0,39 lebih kecil dari 0,05 . Artinya pemanfaatan sosial media $\left(\mathrm{X}_{1}\right)$ secara parsial berpengaruh pada minat berwirausaha (Y). Pemanfaatan sosial media meningkatkan minat untuk berwirausaha.

Hasil penelitian ini didasarkan pada pengertian sosial media adalah fase perubahan mengenai bagaimana orang menemukan, membaca dan membagibagikan berita, informasi dan konten kepada orang lain menurut Kartajaya (2008). Pengukuruan tingkat penggunaan sosial media disini menggunakan tiga dimensi yang mengadopsi dari jurnal yaitu Sarana Komunikasi (Communication), Akses (Accessibility), Pemanfaatan (Usability) yang dilakukan oleh Maharani dkk, 2012).

Berdasarkan uji hipotesis kedua, nilai $\mathrm{t}$ - hitung pada variabel motivasi $\left(\mathrm{X}_{2}\right)$ sebesar 3.045 lebih besar dari 1,66 dan nilai signifikan 0,042 lebih kecil dari 0,05 Artinya motivasi $\left(\mathrm{X}_{2}\right)$ secara parsial berpengaruh signifikan terhadap minat berwirausaha (Y) peningkatan motivasi meningkatkan minat untuk berwirausaha. 
Hasil penelitian ini didasarkan pada pengertian menurut Sumarsono (2003) menyatakan bahwa motivasi berarti pemberian suatu motivasi dalam menggerakkan seseorang atau yang dapat menimbulkan dorongan atau keadaan. Jadi dapat pula dikatakan bahwa motivasi adalah faktor yang mendorong orang untuk bertindak secara sederhana. Selanjutnya Widyastuti dkk, (2004) menyatakan bahwa motivasi seringkali diartikan sebagai dorongan. Dorongan atau tenaga tersebut merupakan gerak jiwa dan jasmani untuk berbuat, sehingga motivasi merupakan suatu tenaga yang menggerakkan manusia untuk bertingkah laku di dalam perbuatannya yang mempunyai tujuan tertentu.

Berdasarkan uji hipotesis ketiga nilai $\mathrm{t}$ - hitung pada variabel pengetahuan kewirausahaan $\left(\mathrm{X}_{3}\right)$ sebesar -1.189 lebih kecil dari 1,66 dan nilai signifikan -0,152 lebih besar dari 0,05 artinya pengetahuan kewirausahaan $\left(\mathrm{X}_{3}\right)$ secara parsial tidak berpengaruh signifikan pada minat berwirausaha (Y).

Hasil penelitian ini didasarkan pada pengertian menurut (Indianti dan Rostianti 2008) mengatakan bahwa pengetahuan kewirausahaan adalah proses transmisi pengetahuan dan keterampilan kewirausahan kepada siswa untuk membantu mereka dalam memanfaatkan pelauang bisnis. Hal ini menyatakan bahwa penddikan kewirausahaan mampu membekali peserta didik dengan berbagai kompetensi kewirausahaan yang diharapkan memberikan manfaat besar dalam segala segi kehidupan. Pendapat ini diperkuat oleh Saroni (2006) yang menjelaskan bahwa pendidikan kewirausahaan adalah program pendidikan yang menggarap aspek kewirausahaan sebagai bagian terpenting dalam pembekalan kompentensi anak didik.

Hasil uji-t yang telah dikemukakan diatas secara lengkap dapat dilihat dalam tabel di bawah ini sebagai berikut:

Tabel 1. Hasil Uji t

Coefficients $^{\mathrm{a}}$

\begin{tabular}{|c|c|c|c|c|c|}
\hline \multirow[b]{2}{*}{ Model } & \multicolumn{2}{|c|}{$\begin{array}{c}\text { Unstandardized } \\
\text { Coefficients }\end{array}$} & \multirow{2}{*}{$\begin{array}{c}\begin{array}{c}\text { Standardize } \\
\mathrm{d}\end{array} \\
\text { Coefficients } \\
\text { Beta }\end{array}$} & \multirow[b]{2}{*}{$\mathrm{t}$} & \multirow[b]{2}{*}{ Sig. } \\
\hline & $B$ & $\begin{array}{l}\text { Std. } \\
\text { Error }\end{array}$ & & & \\
\hline $1 \quad$ (Constant) & 18,111 & 1,825 & & 9.922 & .000 \\
\hline Sosial media & $.0,87$ & .042 & .131 & 2.073 & .039 \\
\hline Motivasi & .118 & .039 & .193 & 3.045 & .042 \\
\hline $\begin{array}{l}\text { Pengetahuan } \\
\text { Kwu }\end{array}$ & -.057 & .048 & -.074 & -1.189 & -.152 \\
\hline
\end{tabular}

a. Dependent Variable: Minat Berwirausaha

Sumber : Data diolah 2015

Berdasarkan uji hipotesis keempat, diperoleh hasil uji-f bahwa bahwa variabel pemanfaatan sosial media, motivasi dan pengetahuan kewirausahaan secara simultan atau bersama - sama berpengaruh signifikan terhadap minat berwirausaha, hal ini terlihat dari nilai $\mathrm{F}$ hitung yang dihasilkan sebesar 5,587 lebih besar $\mathrm{F}$ tabel sebsar 2,65 dengan nilai signifikan 0,01 . 
Hasil Uji F yang telah dikemukakan diatas secara lengkap dapat dilihat dalam tabel di bawah ini sebagai berikut:

Tabel 2. Hasil Uji F

ANOVA $^{b}$

\begin{tabular}{|c|c|c|c|c|c|c|}
\hline Model & & $\begin{array}{l}\text { Sum of } \\
\text { Squares }\end{array}$ & Df & $\begin{array}{l}\text { Mean } \\
\text { Square }\end{array}$ & $\mathrm{F}$ & Sig. \\
\hline 1 & $\begin{array}{l}\text { Regressio } \\
n\end{array}$ & 73,035 & 3 & 24,345 & 5,587 &, $001^{a}$ \\
\hline & Residual & 1058,819 & 243 & 4,357 & & \\
\hline & Total & 1131,854 & 246 & & & \\
\hline
\end{tabular}

a. Predictors: (Constant), X3.TOTAL, X1.TOTAL, X2.TOTAL

b. Dependent Variable: Y1.TOTAL

Sumber : Data diolah, (2015)

\section{SIMPULAN}

Berdasarkan hasil penelitian, dapat disimpulkan bahwa: 1) Terdapat pengaruh pemanfaatan sosial media pada minat berwirausaha mahasiswa Fakultas Ekonomi Universitas Muhammadiyah Sidoarjo. Artinya apabila mahasiswa memanfaatkan sosial media yang maksimal maka minat mahasiswa untuk berwirausaha melalui sosial media akan tinggi. 2) Terdapat pengaruh motivasi pada minat berwirausaha mahasiswa Fakultas Ekonomi Universitas Muhammadiyah Sidoarjo. Artinya motivasi yang tinggi akan meningkatkan minat mahasiswa untuk berwirausaha. 3) Tidak ada pengaruh signifikan pada pengetahuan kewirausahaan terhadap minat berwirausaha mahasiswa Fakultas Ekonomi Universitas Muhammadiyah Sidoarjo. Artinya secara parsial pengetahuan tidak berpengaruh terhadap minat berwirausaha karena tanpa adanya pengetahuan secara parsial maka masih akan terdapat minat mahasiswa untuk berwirausaha. 4) Pengaruh pemanfaatan sosial media, motivasi dan pengetahuan mahasiswa terhadap minat berwirausaha mahasiswa fakultas Ekonomi Universitas Muhammadiyah Sidoarjo adalah signifikan. Hal ini menggambarkan bahwa ketiga variabel bebas tersebut memiliki peran untuk meningkatkan minat berwirausaha yang baik bagi mahasiswa Fakultas Ekonomi Universitas Muhammadiyah Sidoarjo.

Berdasarkan simpulan penelitian, maka disarankan: 1) Kekurangan dari variabel Pemanfaatan sosial media yaitu dari sisi banyaknya mahasiswa yang cenderung memanfaatkan sosial media untuk bermain dan bersenang - senang dan tergolong untuk ajang pamer. 2) Kekurangan dari variabel motivasi yaitu dari sisi lingkungan keluarga dikarenakan dari lingkungan keluarga lebih memilih anaknya bersekolah di universitas muhammadiyah sidoarjo agar mendapatkan pekerjaan yang lebih baik diperusahaan besar.sehingga mahasiswa cenderung menganggap wirausaha adalah bukan jaminan pekerjaan yang layak. 3) Sedangkan kekurangan dari variabel pengetahuan berwirausaha yaitu dari sisi banyaknya mahasiswa fakultas Ekonomi di Universitas Muhammadiyah Sidoarjo yang tidak melanjutkan untuk berwirausaha setelah mendapatkan pengetahuan ilmu kewirausahaan dari segi praktek dan teori. 


\section{DAFTAR RUJUKAN}

Alma, Buchari.(2013). Kewirausahaan Edisi Revisi Cetakan Delapanbelas. Bandung: Alfabeta.

Indianti. dan Rostianti R. (2008). “Intensi Kewirausahaan Mahasiswa: Studi Perbandingan Antara Indonesia, Jepang dan Norwegia" .Jurnal Ekonomika dan Bisnis Indonesia, Vol. 23, No 4

Ghozali Imam 2005. Aplikasi Analisis Multivariate dengan program SPSS Edisi 3, Penerbit Peneliti Universitas Diponegoro, Semarang

Kartajaya, Hermawan. 2008. New Wave Marketing. Jakarta : PT Gramedia Pustaka Hutama

Maharani, Mutia dkk. 2012. Faktor-Faktor Pengaruh Media Sosial Terhadap Keunggulan Bersaing : Studi Kasus Cofee Tofee Indonesia. Moore, Carlos, W. 2001. Kewirausahaan ; Manajemen

Saroni,Muhammad. 2006. Manajemen Sekolah : Kiat Menjadi pendidik yang kompeten.Yogjakarta : Aruzz

Saiman Leornadus,2009, Kewirausahaan : Teori, Prkatek, dan Kasus-kasus, Jakarta, Salemba Empat.

Sumarsono, Sonni, 2003. Ekonomi Manajemen Sumber Daya Manusia dan Ketenagakerjaan, Yogyakarta: Graha Ilmu.

Widyastuti, Suryaningsum dan Juliana . 2004. "Pengaruh Motivasi Terhadap Minat Mahasiswa Untuk Mengikuti Pendidikan Profesi Akuntansi”. Simposium Nasional Akuntansi VII. 